\title{
PERSEPSI KONSUMEN TERHADAP WARNA, TIPOGRAFI, BENTUK GRAFIS DAN GAMBAR PADA KEMASAN PRODUK DENGAN PENDEKATAN MULTIDIMENSIONAL SCALING
}

\author{
Ariesta Sekarlaranti \\ Shellyana Junaedi (shellyanajunaedi@yahoo.com) \\ Universitas Atma Jaya Yogyakarta
}

\begin{abstract}
The aim of this research is to understand consumer perception of color, typography, graphical form and picture at product packaging using multidimensional scaling. Result from this research successfully understands consumer perception to color, typography, graphical form and picture at product packaging. This research concluded that positioning product simply influences packaging design. So packaging company cannot disregard graphical element in design packaging because correct combination between graphical elements of packaging can assist company to create packaging that is not only interesting but also can communicate visually carefully. Result of research is expected able to become benchmark for packaging company in making packaging design.
\end{abstract}

Keywords: color, typhografy, graphical form, picture, product packaging, consumer perception, multidimensional scaling, correspondence analysis

\section{PENDAHULUAN}

Saat berbelanja di swalayan, konsumen dihadapkan pada beragam pilihan produk yang diletakkan di dalam sebuah rak. Puluhan bahkan ratusan produk diletakkan di dalam rak tersebut, sehingga persaingan yang terjadi antar produk semakin kompetitif, terutama untuk produk yang sejenis. Kondisi ini membuat para pemasar semakin menyadari pentingnya membentuk diferensiasi dan identitas produk sehingga konsumen dapat membedakan produk dengan produk pesaingnya (Underwood 2003, yang dikutip oleh Ampuero dan Vila, 2006). Salah satu cara untuk membentuk diferensiasi dan identitas produk adalah melalui kemasan. Tanpa kemasan, konsumen sulit untuk mengenali produk satu dengan produk lainnya karena semua produk akan tampak sama.

Giovanetti (1995) dalam Ampuero dan Vila (2006) mengungkapkan bahwa kemasan memiliki peran penting saat konsumen melakukan pembelian karena kemasan adalah hal yang pertama kali dilihat oleh konsumen sebelum memutuskan untuk membeli produk. Sehingga kemasan dapat dimanfaatkan oleh produsen untuk membujuk konsumen agar membeli produk tanpa melihat merek (McDaniel \& Baker, 1977 dalam Ampuero dan Vila, 2006). Sebuah artikel di majalah Cakram juga menuliskan bahwa $38 \%$ konsumen membeli produk karena kemasannya (http://branderxcentric.blogspot.com/2006/08/packagingindustry-review.html).

Mempertimbangkan fungsi kemasan yang sangat penting bagi produk, para pemasar semakin menyadari bahwa kemasan harus didesain dengan baik agar kemasan mampu menyampaikan identitas produk kepada konsumen sesuai dengan yang diharapkan oleh pemasar. Maka sangat penting bagi para pemasar untuk mengetahui positioning produk terlebih dahulu sebelum mendesain kemasan produk karena setiap strategi positioning membutuhkan desain kemasan yang berbeda. Perbedaan tersebut dapat dilihat dari dua elemen kemasan yaitu elemen struktural yaitu elemen struktural yang terdiri dari terdiri dari bentuk kemasan, ukuran kemasan dan material kemasan dan elemen grafis yang terdiri dari warna, tipografi, bentuk grafis dan gambar. 


\section{Ariesta Sekarlaranti Shellyana Junaedi}

Elemen struktural dan elemen grafis yang merupakan tampilan visual kemasan sering menjadi salah satu faktor yang mendorong konsumen melakukan pembelian (Klimchuk dan Krasovec, 2007:36). Artikel di majalah Marketing menuliskan bahwa kemasan harus memiliki kemampuan untuk berkomunikasi secara visual dengan baik. Berdasarkan penelitian, konsumen menggunakan dua pertiga waktunya untuk melihat produk lebih kepada tampilan visual dibandingkan teks. Konsumen di Indonesia juga banyak yang lebih memperhatikan tampilan visual dibandingkan dengan membaca informasi di kemasan. Oleh karena itu kemasan harus didesain dengan baik tanpa mengabaikan salah satu dari elemen kemasan karena jika dalam mendesain kemasan, para pemasar hanya fokus pada salah satu elemen saja maka sulit untuk mendesain kemasan yang baik. (http://www.marketing.co.id/Common/File.ashx?ld=4621).

Penelitian yang dilakukan oleh Olga Ampuero dan Natalia Vila (2006) terhadap konsumen di Spanyol tentang persepsi terhadap kemasan produk menjadi inspirasi untuk diterapkan di Indonesia. Kurangnya perhatian para pemasar terhadap desain kemasan terutama dari segi elemen grafis kemasan yaitu warna, tipografi, bentuk grafis dan gambar mendorong pentingnya dilakukan sebuah penelitian tentang elemen grafis kemasan. Untuk menghasilkan kemasan yang baik, para pemasar diharapkan tidak hanya mementingkan unsur fungsional kemasan namun juga mempertimbangkan unsur estetikanya karena tampilan visual sangat penting bagi sebuah produk, baik sebagai alat diferensiasi produk yang dapat menarik perhatian konsumen sehingga mudah dikenali konsumen dan pada akhirnya dapat membuat konsumen memutuskan untuk melakukan pembelian. Namun yang paling penting adalah desain kemasan dengan tampilan visual yang baik dapat membantu para pemasar untuk berhasil memposisikan produk di benak konsumen

\section{LANDASAN TEORI DAN PENGEMBANGAN HIPOTESIS}

\section{Kemasan}

Menurut Giovannetti (1995) dalam Ampuero dan Vila (2006:103) kemasan terdiri dari tiga tipe yaitu :

1. Kemasan utama (primary packaging) yaitu kemasan yang memiliki kontak langsung dengan produk.

2. Kemasan kedua (secondary packaging) yaitu kemasan yang berfungsi sebagai alat pelindung, alat identifikasi dan alat untuk mengkomunikasikan kualitas produk. Pada umumnya, kemasan ini akan dibuang saat produk mulai digunakan atau dikonsumsi.

3. Kemasan tambahan (tertiary packaging) yaitu kemasan yang membungkus dua kemasan sebelumnya (kemasan utama dan kemasan kedua). Kemasan ini berfungsi sebagai alat penyatu dan pelindung produk selama berada di dalam perjalanan di saluran distribusi

Berkowitz et al (1992) dalam Tjiptono (1997:106-107) mengemukakan tiga manfaat utama dari kemasan, yaitu manfaat komunikasi, manfaat fungsional dan manfaat perseptual.

1. Manfaat komunikasi

Manfaat komunikasi merupakan manfaat utama dari kemasan. Informasi produk seperti cara pemakaian produk, komposisi produk dan informasi-informasi lainnya disampaikan melalui kemasan kepada konsumen.

2. Manfaat fungsional Kemasan mempunyai manfaat fungsional yang penting seperti memberikan kemudahan, perlindungan dan penyimpanan produk.

3. Manfaat perseptual

Kemasan dapat menanamkan persepsi tertentu ke dalam benak konsumen dilihat dari elemen-elemen yang terdapat pada kemasan seperti warna, ukuran, bentuk maupun bahan pembuatan kemasan. 


\section{Positioning}

Positioning sangat penting untuk dilakukan oleh pemasar di dalam lingkungan persaingan yang semakin kompetitif. Jika pemasar mampu melakukan positioning dengan baik maka konsumen dapat mengenali citra perusahaan yang berbeda dengan para pesaingnya. Karena pada dasarnya, positioning merupakan strategi penting untuk menciptakan diferensiasi yang unik sehingga terbentuk citra produk atau merek yang lebih unggul dibandingkan dengan para pesaing di dalam benak konsumen (Tjiptono, 1997:109).

\section{Dasar-dasar Desain Kemasan}

Menurut Shimp (2003:317) karena kemasan sangat penting untuk kesuksesan sebuah merek maka diperlukan pendekatan sistematis dalam mendesain kemasan :

1. Tahap 1 : Menentukan Tujuan Positioning Merek

Positioning merupakan dasar bagi pemasar dalam mendesain sebuah kemasan. Pemasar harus memutuskan bagaimana merek akan diposisikan di benak konsumen agar dapat terlihat berbeda dengan kompetitor.

2. Tahap 2 : Melakukan Analisis Kategori Produk

Setelah menentukan positioning dari merek, pemasar perlu mengetahui kategori produk merek sehingga dapat menentukan desain kemasan yang tepat yang sesuai dengan karakteristik produk tersebut.

3. Tahap 3 : Melakukan Analisis Kompetitif

Setelah menentukan kemasan yang tepat untuk sebuah produk, para pemasar harus mengamati produk kompetitor agar dapat menciptakan kemasan sesuai dengan positioning yang diinginkan sehingga dapat terlihat berbeda dengan para pesaingnya.

4. Tahap 4 : Mengidentifikasi Atribut/Manfaat Produk yang Menonjol

Dalam mendesain kemasan, para pemasar harus mampu menyeleksi informasi utama dari sekian banyak informasi yang akan ditampilkan agar kemasan dapat efektif menyampaikan informasi produk kepada konsumen karena menurut penelitian yang dilakukan, konsumen menghabiskan waktu sekitar 10 hingga 12 detik untuk melihat produk sebelum melakukan keputusan pembelian.

5. Tahap 5 : Menentukan Prioritas Komunikasi

Pada tahap ini para pemasar akan memutuskan informasi yang paling penting di antara informasi yang telah dipilih pada tahap 4 sehingga diharapkan kemasan dapat menarik perhatian konsumen.

\section{Elemen Grafis Kemasan}

Elemen grafis kemasan terdiri dari empat elemen yaitu warna, tipografi, bentuk grafis dan gambar.

1. Warna

Menurut Klimchuk dan Krasovec (2007:107), warna merupakan salah satu elemen grafis yang berpengaruh dari sebuah kemasan karena saat melihat kemasan, konsumen cenderung memperhatikan warna kemasan terlebih dahulu sebelum mengamati unsur-unsur visual kemasan lainnya. Dalam mendesain kemasan, pemilihan warna sangat penting karena dapat menimbulkan respon tertentu terhadap konsumen. Berikut adalah arti dan makna dari masing-masing warna (Klimchuk dan Krasovec, 2007:108:112).

a. Merah

Warna merah menggambarkan cinta, api, nafsu, agresi, sifat impulsif, mendebarkan, berani, kuat, kecanggihan, kesetiaan, keotentikan, keseriusan dan efektifitas.

b. Oranye 


\section{Ariesta Sekarlaranti Shellyana Junaedi}

Warna oranye melambangkan energi, suka cita, antusiasme, petualangan, ceria dan kepuasan.

c. Kuning

Warna kuning menggambarkan sebuah kehidupan, kehangatan, idealisme, energi dan sportif.

d. Hijau

Warna hijau menggambarkan warna yang membumi, damai, hidup, muda, segar, organik, kesuburan, lingkungan, keberuntungan dan kemakmuran.

e. Biru

Warna biru melambangkan otoritas, harga diri, kesetiaan, kebenaran, kebijaksanaan, keyakinan, kekuatan, konservatif, kepercayaan, stabilitas dan keamanan.

f. Ungu

Warna ungu melambangkan kepuasan, kebangsawanan, kemewahan, kemakmuran, kebijaksanaan, spiritual, sensual, misteri, nafsu dan keberanian.

g. Coklat

Warna coklat melambangkan warna yang membumi, dapat dipercaya, nyaman dan daya tahan.

h. Hitam

Warna hitam menggambarkan keandalan, kekuatan, kebijaksanaan, keberanian, kewaspadaan, keseriusan, kekayaan, elegan, kesempurnaan dan kemewahan.

i. Putih

Warna putih merefleksikan cahaya serta dapat membuat warna di sekitarnya terlihat menonjol. Warna putih menggambarkan kemurnian, kesegaran, kesucian, kebersihan, keefektifan dan kebenaran.

2. Tipografi

Tipografi adalah sebuah ilmu dalam desain grafis yang mempelajari tentang seluk beluk huruf (Sihombing, 2001:3) Tipografi sering digunakan sebagai pedoman untuk mendesain tulisan yang akan digunakan baik pada iklan maupun kemasan. Kusrianto (2007:202) menuliskan tipe-tipe huruf yang ada di dalam ilmu tipografi :

a. Huruf Serif

Huruf Serif mempunyai ciri yang khas yaitu memiliki garis-garis kecil (counter strokes) di setiap ujung hurufnya. Contoh dari tipe huruf Serif yaitu Times New Roman, Garamond, Book Antiqua dan Georgia.

b. Huruf Sans Serif

Huruf Sans Serif tidak memiliki garis-garis kecil di setiap ujung hurufnya, memiliki karakteristik streamline, fungsional, modern dan kontemporer. Contoh jenis huruf ini adalah Arial, Franklin Gothic dan Century Cothic.

c. Huruf Script

Tipe huruf Script menyerupai tulisan tangan sehingga mempunyai kesan yang alami. Contoh tulisan yang termasuk di dalam tipe huruf Script adalah Freeport, Monotype Corsiva dan Lucida Handwritting.

Dalam mendesain sebuah kemasan, tipografi yang digunakan harus mudah dibaca dari jarak beberapa kaki jauhnya. Selain itu, tipografi kemasan juga diharapkan mampu untuk mengkomunikasikan informasi produk dengan jelas (Klimchuk dan Krasovec, 2007:92).

3. Bentuk Grafis

Klimchuk dan Krasovec (2007:131-135) menjelaskan bahwa bentuk-bentuk grafis pada kemasan dapat digunakan untuk membantu mengatur informasi visual kemasan, membangun perasaan tertentu, mengarahkan mata konsumen saat membaca teks pada kemasan dan memisahkan tulisan-tulisan yang terdapat pada kemasan. Bentuk grafis juga memiliki makna konotasi yang berbeda-beda. Berikut ini adalah jenis bentuk grafis beserta makna konotasinya: 
a. Bentuk Garis

Garis mempunyai makna konotasi yang berbeda-beda yaitu (Kusrianto, 2007:46 dan Shimp, 2003:307) :

1) Garis Lurus

Garis lurus mempunyai makna kuat, kokoh dan tegas. Garis lurus dapat dibedakan lagi menjadi tiga kelompok yaitu garis horizontal, garis vertikal dan garis miring. Garis horizontal melambangkan ketenangan, kesegaran dan dapat menimbulkan perasaan tenteram. Garis vertikal melambangkan perasaan kuat, kokoh, tegas, kepercayaan diri dan kebanggaan. Sedangkan garis miring mempunyai makna kekuatan.

2) Garis Lengkung Garis lengkung melambangkan suatu kelemahlembutan, keanggunan dan berkonotasi feminin.

3) Garis Zigzag Garis zigzag melambangkan ketajaman dan ketegasan.

b. Bentuk Geometris

Menurut Kristianto (2002), berikut adalah makna dari bentuk-bentuk geometris (faculty.petra.ac.id):

1) Segitiga

Segitiga melambangkan energi, kekuatan, keseimbangan, hukum, ilmu pasti dan agama, menggambarkan kesan maskulin seperti kekuatan, agresi, dan pergerakan yang dinamik.

2) Kotak Kotak melambangkan keteraturan, logis dan keamanan.

3) Lingkaran

Lingkaran melambangkan koneksi, komunitas, keseluruhan, ketahanan, pergerakan dan keamanan, menggambarkan kesan kewanitaan seperti kehangatan, kenyamanan, sensualiatas, dan cinta.

4. Gambar

Klimchuk dan Krasovec (2007:119) mengungkapkan bahwa penggunaan gambar dalam kemasan dapat menarik perhatian konsumen karena pada umumnya konsumen melihat gambar sebelum membaca teks. Gambar dibedakan menjadi dua kelompok yaitu fotografi dan ilustrasi. Dalam mendesain sebuah kemasan, pemasar harus jeli dalam memilih dan mengolah gambar yang akan ditampilkan pada kemasan karena kesan yang ditimbulkan jika menggunakan fotografi akan berbeda jika menggunakan ilustrasi. Penggunaan gambar pada kemasan harus disesuaikan dengan produk karena pemilihan gambar yang tepat dapat membantu para pemasar agar pesan yang disampaikan melalui gambar pada kemasan dapat diterima konsumen dengan jelas.

\section{Persepsi Konsumen}

Persepsi adalah sebuah proses yang dilakukan oleh individu untuk memilih, mengatur dan menafsirkan stimulus tertentu. Setiap stimulus yang diterima antara orang yang satu dengan yang lainnya bisa jadi menghasilkan persepsi yang berbeda karena kepekaan terhadap stimulus berbeda-beda, tergantung dari kualitas pancaindera dan kekuatan stimulus yang diterima (Schiffman dan Kanuk, 2007:137).

Dalam desain kemasan, pemasar akan merancang kemasan yang berbeda dengan pesaingnya dengan mempertimbangkan elemen struktural dan elemen grafis kemasan. Pemilihan warna, tipografi, bentuk grafis maupun gambar yang tepat pada kemasan diharapkan dapat memberikan stimulus yang kuat kepada konsumen sehingga konsumen 


\section{Ariesta Sekarlaranti Shellyana Junaedi}

dapat mempunyai persepsi tertentu terhadap merek dan mampu mengingat merek dengan baik.

\section{Pengembangan Hipotesis}

Tampilan visual kemasan yaitu elemen struktural dan elemen grafis harus didesain dengan baik agar dapat menghasilkan kemasan yang mampu menunjukkan positioning produk yang jelas kepada konsumen. Ampuero dan Vila (2006) mengungkapkan bahwa kombinasi yang tepat antara elemen-elemen grafis dapat menciptakan kemasan yang menarik dimana penggunaan warna, tipografi, bentuk grafis dan gambar pada kemasan harus disesuaikan positioning produk agar kemasan benar-benar dapat mengkomunikasikan identitas produk kepada konsumen dengan jelas. Maka penelitian ini mengungkapkan bahwa konsumen mempunyai persepsi terhadap warna, tipografi, bentuk grafis dan gambar pada kemasan produk sesuai dengan strategi positioning yang diterapkan pada kemasannya, sehingga hipotesis pada penelitian ini adalah :

$\mathrm{H} 1$. Konsumen mempunyai persepsi yang bervariasi terhadap warna pada kemasan produk sesuai dengan strategi positioning yang diterapkan pada kemasannya.

H2. Konsumen mempunyai persepsi yang bervariasi terhadap tipografi pada kemasan produk sesuai dengan strategi positioning yang diterapkan pada kemasannya.

H3. Konsumen mempunyai persepsi yang bervariasi terhadap bentuk grafis pada kemasan produk sesuai dengan strategi positioning yang diterapkan pada kemasannya.

H4. Konsumen mempunyai persepsi yang bervariasi terhadap gambar pada kemasan produk sesuai dengan strategi positioning yang diterapkan pada kemasannya.

\section{METODE PENELITIAN}

Pengumpulan data yang dilakukan di dalam penelitian ini menggunakan teknik pengumpulan data yang dilakukan oleh Ampuero dan Vila (2006) tentang persepsi konsumen terhadap kemasan produk. Subyek penelitian adalah konsumen yaitu mahasiswa-mahasiswi di Universitas Atma Jaya Yogyakarta sedangkan obyek penelitian adalah warna, tipografi, bentuk grafis dan gambar pada kemasan produk. Responden sebanyak 100 responden dengan teknik pengambilan sampel convenience sampling yaitu teknik pengambilan sampel dimana saat melakukan penelitian, populasi yang ditemui peneliti bersedia menjadi responden dan dijadikan sampel. Teknik ini cocok untuk menguji atau mencari ide-ide baru yang bersifat eksploratif (Suliyanto, 2006:124).

Bentuk penelitian adalah eksperimen. Tahap pertama, responden diberi sebuah gambar yang berisi contoh elemen grafis yaitu warna, tipografi, bentuk grafis dan gambar. Enam gambar disiapkan untuk elemen grafis warna. Untuk instrumen brightness disiapkan dua contoh gambar yaitu gambar berwarna gelap dan berwarna terang. Kedua, instrumen saturation terdiri dari gambar berwarna pudar dan berwarna pekat. Ketiga, instrumen temperatur warna terdiri dari warna hangat yaitu merah, oranye, kuning, sedangkan warna sejuk terdiri dari hijau dan biru. Instrumen shade terdiri dari shade 1 yaitu putih dan hitam, shade 2 yaitu hijau dan biru, sedangkan shade 3 yaitu kuning, oranye dan merah. Langkahlangkah yang sama juga dipersiapkan untuk instrumen tipografi, bentuk grafis dan gambar. Kemudian contoh gambar ditunjukkan kepada para responden untuk mengasosiasikan antara strategi positioning Blankson \& Kalafatis (2001) dengan elemen grafis yang ada.

Tahap kedua, responden diberi penjelasan tentang salah satu strategi positioning produk. Misalnya, produk A diposisikan sebagai produk yang ditujukan untuk kelas atas. Tahap selanjutnya, responden diminta untuk memilih kemasan yang paling sesuai untuk produk $A$ dengan melihat gambar elemen grafis yang sebelumnya telah ditunjukkan kepada responden. Kedua tahap ini diulangi untuk enam tipologi positioning yang lain. Tahap keempat adalah menghitung jumlah elemen grafis yang telah dipilih oleh responden. 
Metode analisis data yang digunakan adalah analisis korespondensi yang merupakan salah satu teknik multidimensional scaling non-metrik. Analisis ini digunakan untuk mengetahui melihat bagaimana pemetaan persepsi konsumen terhadap kemasan produk dengan strategi positioning yang berbeda-beda berdasarkan sekumpulan atribut kemasan yaitu elemen grafis yang terdiri dari warna, tipografi, bentuk grafis dan gambar. Interpretasi dilakukan dengan mengamati posisi produk dan elemen grafis di dalam perceptual map. Produk-produk yang memiliki jarak relatif dekat dengan elemen-elemen grafis kemasan di perceptual map menggambarkan kemasan yang sesuai dengan produk tersebut berdasarkan persepsi konsumen. Analisis data dilakukan dengan menggunakan bantuan program SPPS 15 for windows.

Instrumen penelitian diperoleh dari penelitian sebelumnya yang dilakukan oleh Ampuero dan Vila (2006). Di bawah ini adalah gambar dari instrumen penelitian yang terdiri empat elemen grafis kemasan yaitu warna, tipografi, bentuk grafis dan gambar. 


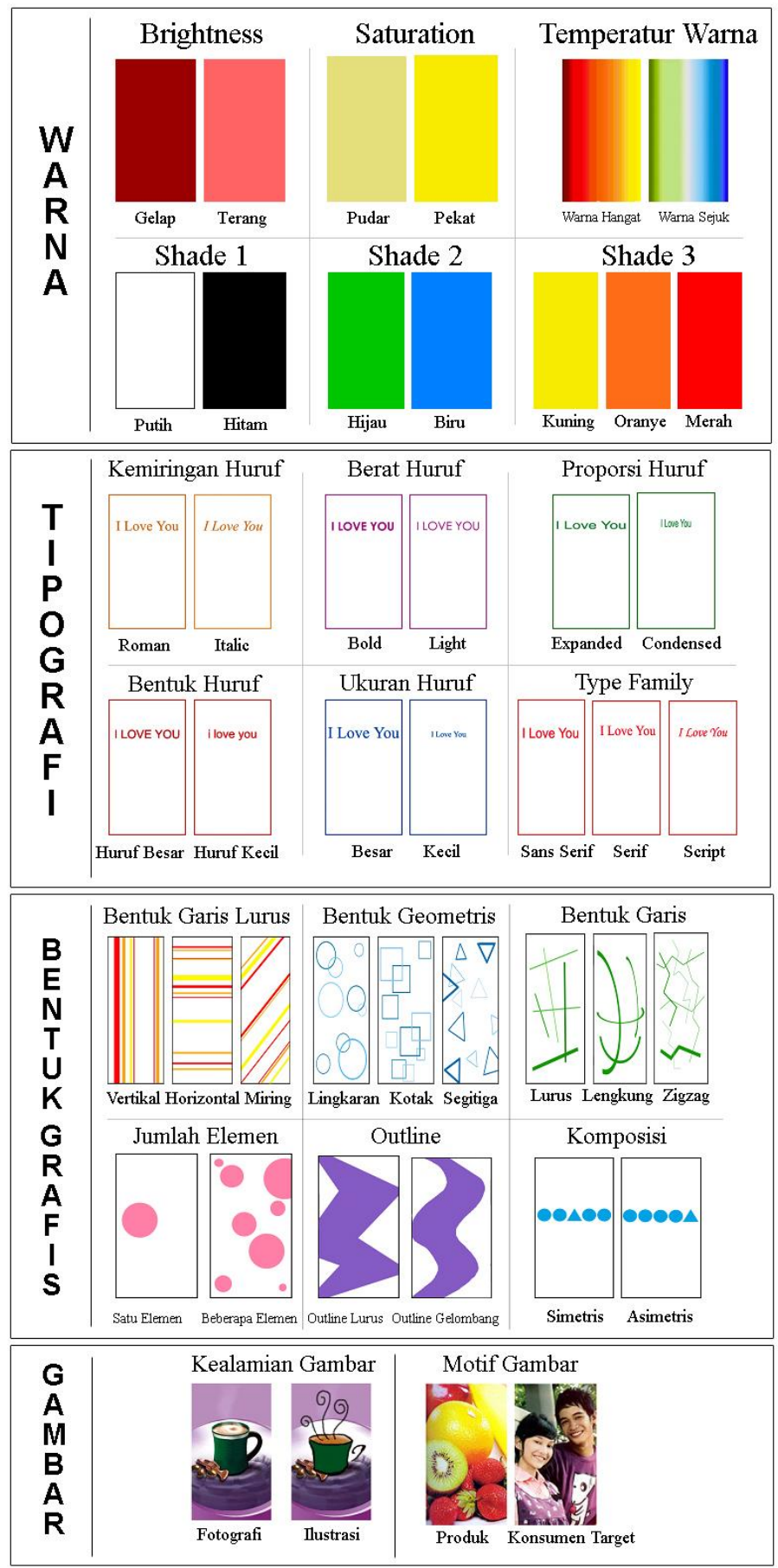

Gambar 1. Instrumen Penelitian

\section{HASIL PENELITIAN DAN PEMBAHASAN}

Responden berjumlah 100 orang. 100 responden tersebut terdiri dari 50 laki-laki dan 50 perempuan. Usia responden berkisar antara 20 - 22 tahun.

Statistik Deskriptif

Statistik deskriptif digunakan untuk mengetahui frekuensi tertinggi dari warna, tipografi, bentuk grafis dan gambar kemasan yang dipilih oleh responden untuk masing-masing produk. 
Warna Kemasan Produk

Tabel 1

Frekuensi Warna Kemasan Produk

\begin{tabular}{|l|c|c|c|c|c|c|c|}
\hline \multirow{2}{*}{ Jenis Warna } & \multicolumn{7}{|c|}{ Positioning Produk } \\
\cline { 2 - 8 } & $\begin{array}{c}\text { Kelas } \\
\text { Atas }\end{array}$ & $\begin{array}{c}\text { Harga } \\
\text { Ekonomis }\end{array}$ & Aman & Elegan & Lokal & $\begin{array}{c}\text { Bermutu } \\
\text { Tinggi }\end{array}$ & $\begin{array}{c}\text { Kelas } \\
\text { Menengah }\end{array}$ \\
\hline Brightness & & & & & & & \\
Gelap & 62 & 38 & 85 & 61 & 59 & 70 & 36 \\
Terang & 38 & 62 & 15 & 39 & 41 & 30 & 64 \\
\hline Saturation & 32 & 58 & 36 & 42 & 51 & 37 & 44 \\
Pudar & 68 & 42 & 64 & 58 & 49 & 63 & 56 \\
Pekat & & & & & & & \\
\hline Temperatur Warna & 49 & 52 & 65 & 40 & 53 & 65 & 50 \\
Warna Hangat & 51 & 48 & 35 & 60 & 47 & 35 & 50 \\
Warna Sejuk & & & & & & & \\
\hline Shade 1 & 43 & 58 & 45 & 40 & 56 & 34 & 45 \\
Putih & 57 & 42 & 55 & 60 & 44 & 66 & 55 \\
Hitam & & & & & & & \\
\hline Shade 2 & 24 & 61 & 44 & 38 & 58 & 34 & 63 \\
$\quad$ Hijau & 76 & 39 & 56 & 62 & 42 & 66 & 37 \\
Biru & & & & & & & \\
\hline Shade 3 & & & & & & \\
$\quad$ Kuning & 23 & 42 & 36 & 27 & 37 & 30 & 37 \\
$\quad$ Oranye & 33 & 40 & 23 & 43 & 37 & 34 & 34 \\
$\quad$ Merah & 44 & 18 & 41 & 30 & 26 & 36 & 29 \\
\hline
\end{tabular}

Tipografi Kemasan Produk

Tabel 2

Frekuensi Tipografi Kemasan Produk

\begin{tabular}{|c|c|c|c|c|c|c|c|}
\hline \multirow{2}{*}{$\begin{array}{c}\text { Jenis } \\
\text { Tipografi }\end{array}$} & $\begin{array}{c}\text { Kelas } \\
\text { Atas }\end{array}$ & $\begin{array}{c}\text { Harga } \\
\text { Ekonomis }\end{array}$ & Aman & Elegan & Lokal & $\begin{array}{c}\text { Bermutu } \\
\text { Tinggi }\end{array}$ & $\begin{array}{c}\text { Kelas } \\
\text { Menengah }\end{array}$ \\
\hline $\begin{array}{c}\text { Kemiringan Huruf } \\
\text { Roman }\end{array}$ & 30 & 65 & 74 & 30 & 71 & 34 & 35
\end{tabular}


Ariesta Sekarlaranti

Shellyana Junaedi

\begin{tabular}{|l|l|l|l|l|l|l|l|}
$\begin{array}{l}\text { Italic } \\
\text { Berat Huruf }\end{array}$ & 70 & 35 & 26 & 70 & 29 & 66 & 65 \\
$\begin{array}{l}\text { Bold } \\
\text { Light }\end{array}$ & 68 & 42 & 58 & 48 & 56 & 48 & 56 \\
$\begin{array}{l}\text { Proporsi Huruf } \\
\text { Expanded }\end{array}$ & 32 & 58 & 42 & 52 & 44 & 52 & 44 \\
$\begin{array}{l}\text { Condensed } \\
\text { Bentuk Huruf }\end{array}$ & 79 & 29 & 80 & 60 & 65 & 70 & 66 \\
$\quad$ Huruf Besar & 76 & 71 & 20 & 40 & 35 & 30 & 34 \\
$\quad$ Huruf Kecil & 24 & 62 & 73 & 66 & 63 & 66 & 65 \\
$\begin{array}{l}\text { Ukuran Huruf } \\
\text { Ukuran Besar }\end{array}$ & 72 & 40 & 76 & 61 & 70 & 64 & 61 \\
$\quad$ Ukuran Kecil & 28 & 60 & 24 & 39 & 30 & 36 & 39 \\
$\begin{array}{l}\text { Type Family } \\
\text { Sans Serif }\end{array}$ & 14 & 33 & 43 & 14 & 48 & 19 & 26 \\
$\quad \begin{array}{l}\text { Serif } \\
\text { Script }\end{array}$ & 23 & 58 & 38 & 36 & 35 & 31 & 25 \\
\hline
\end{tabular}

Bentuk Grafis Kemasan Produk

Tabel 3

Frekuensi Bentuk Grafis Kemasan Produk

\begin{tabular}{|c|c|c|c|c|c|c|c|}
\hline \multirow{2}{*}{$\begin{array}{c}\text { Jenis } \\
\text { Bentuk Grafis }\end{array}$} & \multicolumn{7}{|c|}{ Positioning Produk } \\
\hline & $\begin{array}{l}\text { Kelas } \\
\text { Atas }\end{array}$ & $\begin{array}{c}\text { Harga } \\
\text { Ekonomis }\end{array}$ & Aman & Elegan & Lokal & $\begin{array}{l}\text { Bermutu } \\
\text { Tinggi }\end{array}$ & $\begin{array}{c}\text { Kelas } \\
\text { Menengah }\end{array}$ \\
\hline \multicolumn{8}{|l|}{ Bentuk Garis Lurus } \\
\hline Vertikal & 62 & 34 & 52 & 42 & 39 & 47 & 38 \\
\hline Horizontal & 19 & 48 & 36 & 25 & 42 & 27 & 29 \\
\hline Miring & 19 & 18 & 12 & 33 & 19 & 26 & 33 \\
\hline \multicolumn{8}{|l|}{ Bentuk Geometris } \\
\hline Lingkaran & 49 & 37 & 42 & 39 & 46 & 47 & 31 \\
\hline Kotak & 46 & 44 & 47 & 39 & 35 & 42 & 45 \\
\hline \multirow{2}{*}{\multicolumn{8}{|c|}{ Bentuk Garis }} \\
\hline & & & & & & & \\
\hline Garis Lurus & 23 & 46 & 53 & 21 & 46 & 35 & 30 \\
\hline Garis Lengkung & 54 & 34 & 38 & 51 & 36 & 39 & 40 \\
\hline $\begin{array}{l}\text { Garis Zigzag } \\
\text { Jumlah Elemen }\end{array}$ & 23 & 20 & 9 & 28 & 18 & 26 & 30 \\
\hline Satu Elemen & 25 & 63 & 39 & 20 & 61 & 32 & 24 \\
\hline Beberapa Elemen & 75 & 37 & 61 & 80 & 39 & 68 & 76 \\
\hline \multicolumn{8}{|l|}{ Outline } \\
\hline $\begin{array}{l}\text { Outline Lurus } \\
\text { Outline }\end{array}$ & 24 & 62 & 40 & 26 & 56 & 33 & 41 \\
\hline Gelombang & 76 & 38 & 60 & 74 & 44 & 67 & 59 \\
\hline $\begin{array}{l}\text { KomposisI } \\
\text { Simetris }\end{array}$ & 79 & 41 & 78 & 61 & 59 & $6]$ & 51 \\
\hline Asimetris & 21 & 59 & 22 & 39 & 41 & 39 & 46 \\
\hline
\end{tabular}

Gambar Kemasan Produk

Tabel 4

Frekuensi Gambar Kemasan Produk

\begin{tabular}{|l|c|c|c|c|c|c|c|}
\hline \multirow{2}{*}{ Jenis Gambar } & \multicolumn{6}{|c|}{ Positioning Produk } \\
\cline { 2 - 7 } & $\begin{array}{c}\text { Kelas } \\
\text { Atas }\end{array}$ & $\begin{array}{c}\text { Harga } \\
\text { Ekonomis }\end{array}$ & Aman & Elegan & Lokal & $\begin{array}{c}\text { Bermutu } \\
\text { Tinggi }\end{array}$ & $\begin{array}{c}\text { Kelas } \\
\text { Menengah }\end{array}$ \\
\hline $\begin{array}{l}\text { Kealamian } \\
\text { Gambar }\end{array}$ & & & & & & & \\
\hline
\end{tabular}




\begin{tabular}{|l|l|l|l|l|l|l|l|} 
Fotografi & 53 & 51 & 74 & 37 & 63 & 53 & 43 \\
Ilustrasi & 47 & 49 & 26 & 63 & 37 & 47 & 57 \\
\hline $\begin{array}{l}\text { Motif Gambar } \\
\begin{array}{l}\text { Produk } \\
\text { Konsumen } \\
\text { Target }\end{array}\end{array}$ & 64 & 55 & 70 & 62 & 46 & 61 & 48 \\
\hline
\end{tabular}

\section{Analisis Korespondensi}

Analisis korespondensi digunakan untuk melihat pemetaan persepsi konsumen terhadap kemasan produk yang memiliki strategi positioning berbeda-beda berdasarkan sekumpulan atribut kemasan yaitu elemen grafis yang terdiri dari warna, tipografi, bentuk grafis dan gambar. Interpretasi dilakukan dengan mengamati posisi produk dan elemen grafis di dalam perceptual map. Produk dengan jarak yang relatif dekat dengan elemen-elemen grafis kemasan di perceptual map menggambarkan kemasan yang sesuai untuk produk tersebut berdasarkan persepsi konsumen. Analisis korespondensi dilakukan dengan menggunakan SPSS 15.00 .

\section{Pemetaan Persepsi Konsumen terhadap Warna Kemasan Produk}

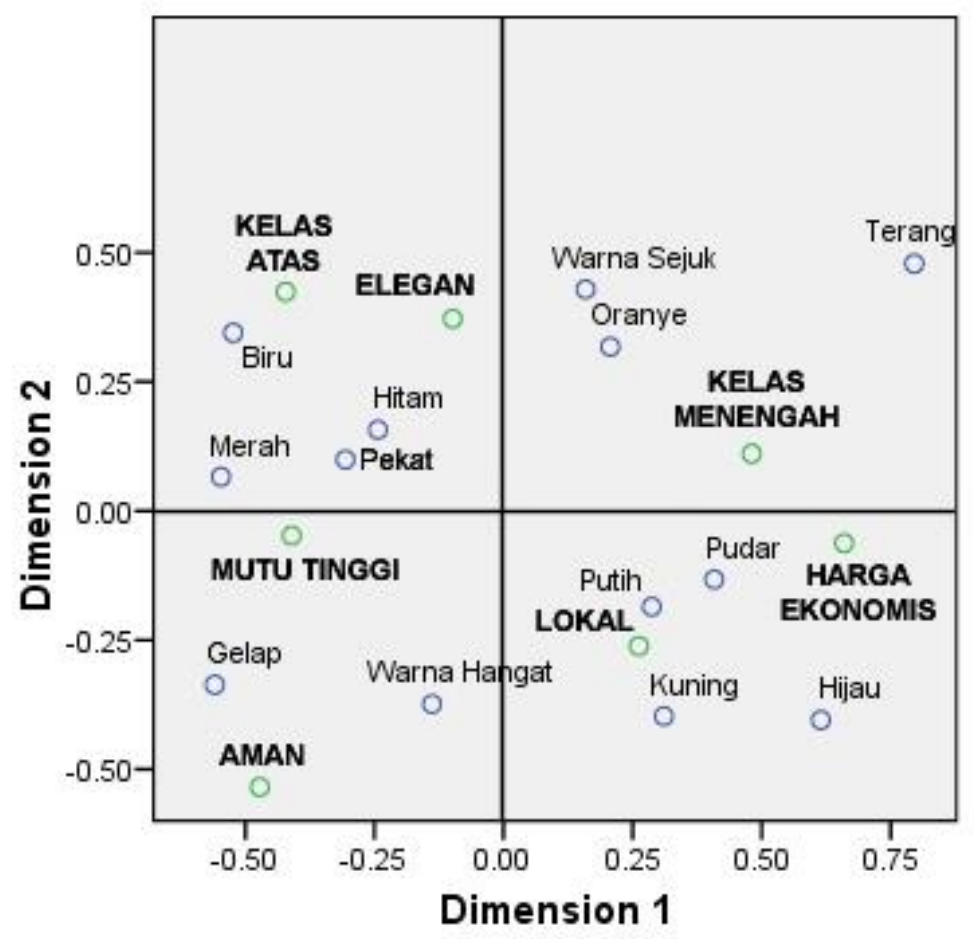

Gambar 2. Perceptual Map Warna Kemasan Produk

Dari perceptual map di atas dapat dilihat bahwa posisi produk untuk kelas atas, produk elegan dan produk bermutu tinggi berada di sekitar warna biru, hitam, merah dan warna yang pekat. Produk yang aman memiliki jarak relatif dekat dengan warna gelap dan warna hangat. Produk lokal dan produk yang memiliki harga ekonomis berdekatan dengan warna putih, kuning, hijau dan warna yang pudar. Sedangkan, produk untuk kelas menengah terletak di sekitar warna warna sejuk, oranye dan terang.

\section{Pemetaan Persepsi Konsumen terhadap Tipografi Kemasan Produk}




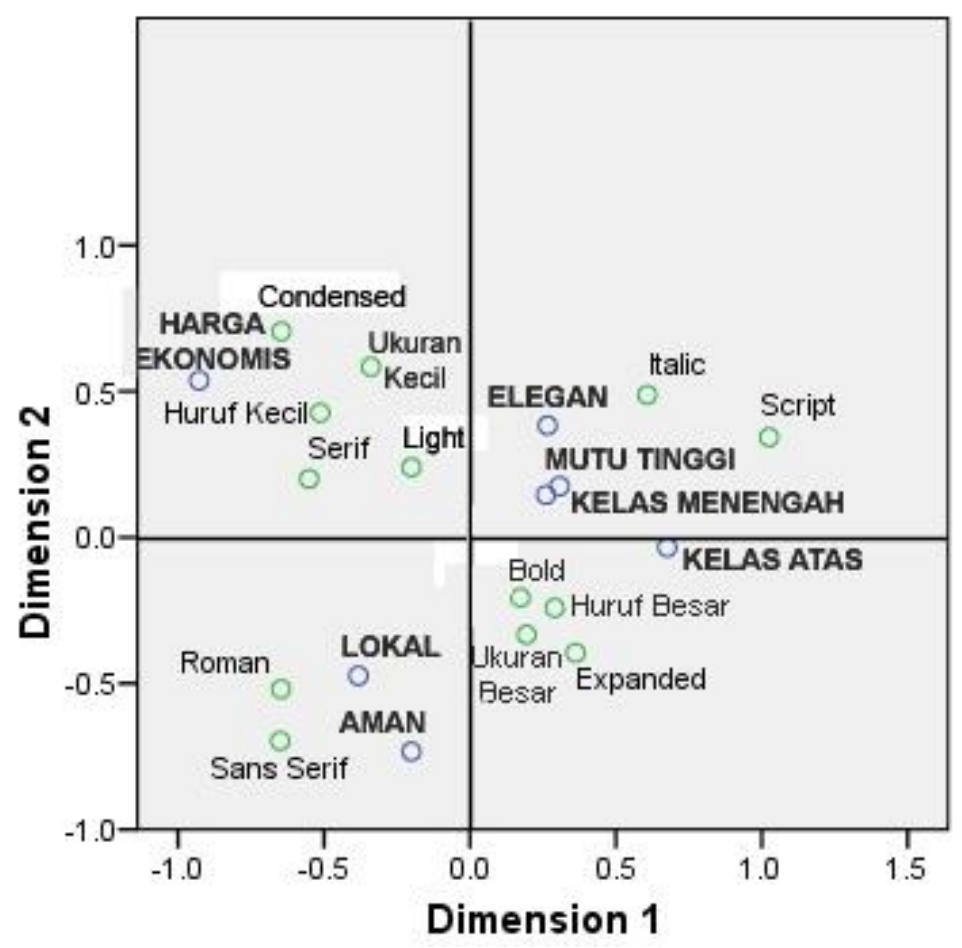

Gambar 3. Perceptual Map Tipografi Kemasan Produk

Dari perceptual map di atas, dapat dilihat bahwa produk untuk kelas atas memiliki posisi yang relatif dekat dengan huruf bold, huruf besar, expanded dan berukuran besar. Produk lokal dan produk yang aman memiliki jarak yang relatif dekat dengan huruf roman dan sans serif. Produk elegan, produk bermutu tinggi dan produk untuk kelas menengah memiliki jarak yang relatif dekat dengan huruf italic dan script. Sedangkan produk harga ekonomis memiliki jarak relatif dekat dengan huruf kecil, serif, light, condensed dan huruf berukuran kecil. 


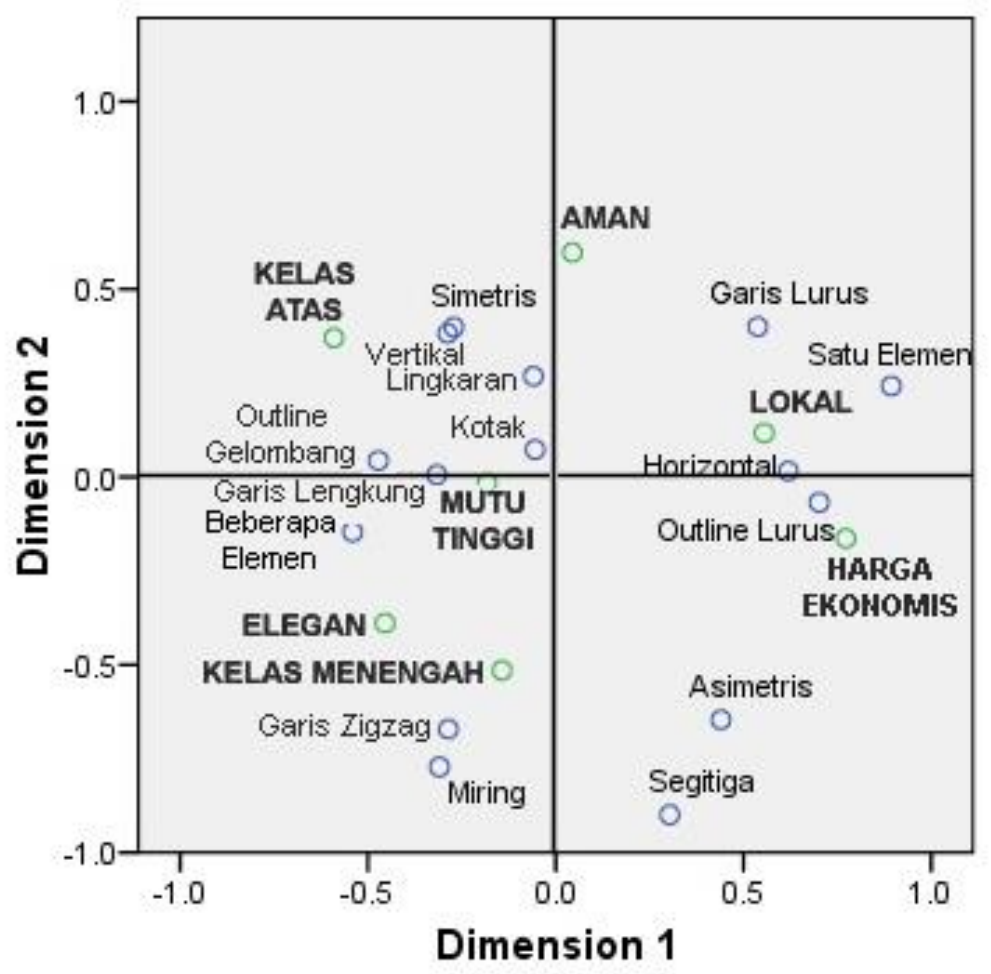

Gambar 4. Perceptual Map Bentuk Grafis Kemasan Produk

Perceptual map di atas menunjukkan bahwa bentuk lingkaran, komposisi simetris dan vertikal terletak di sekitar produk kelas atas dan produk yang aman. Produk bermutu tinggi relatif dekat dengan kotak, garis lengkung, outline gelombang dan beberapa elemen. Produk elegan dan produk untuk kelas menengah memiliki posisi yang relatif dekat dengan garis zigzag dan miring. Sedangkan untuk produk lokal dan produk dengan harga ekonomis terlihat berdekatan dengan garis lurus, outline lurus, horizontal dan satu elemen.

\section{Pemetaan Persepsi Konsumen terhadap Gambar Kemasan Produk}

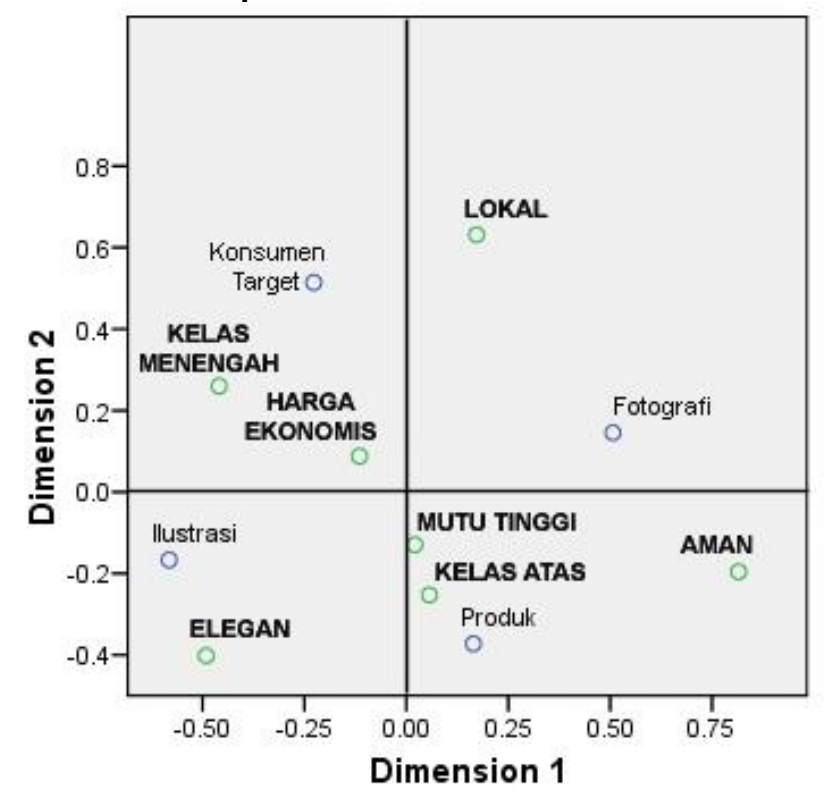

Gambar 5. Perceptual Map Gambar Kemasan Produk 


\section{Ariesta Sekarlaranti Shellyana Junaedi}

Perceptual map di atas menunjukkan bahwa produk untuk kelas atas dan produk bermutu tinggi memliki jarak yang relatif dekat dengan jenis gambar yaitu produk. Produk dengan harga ekonomis, produk yang ditujukan untuk kelas menengah dan produk lokal memiliki posisi yang berdekatan dengan jenis gambar berupa konsumen target. Produk yang diposisikan sebagai produk yang aman relatif dekat dengan jenis gambar kemasan yaitu fotografi. Sedangkan produk elegan terletak di dekat ilustrasi.

\section{KESIMPULAN}

Dari hasil analisis data dapat disimpulkan bahwa konsumen memiliki persepsi terhadap kemasan produk ditinjau dari warna, tipografi, bentuk grafis dan gambar. Persepsi konsumen terhadap kemasan produk bervariasi sesuai dengan strategi positioning yang diterapkan untuk kemasan produk tersebut. Maka perusahaan dapat melihat bahwa positioning produk ternyata mempengaruhi desain kemasan yang akan dibuat khususnya dilihat dari segi grafisnya. Oleh karena itu sangat penting bagi perusahaan kemasan untuk lebih memperhatikan eleman grafis kemasan yang akan dibuat agar sesuai dengan positioning yang ingin ditanamkan di dalam benak konsumen.

Dari perceptual map yang telah dihasilkan dapat dilihat dengan jelas pemetaan persepsi konsumen terhadap setiap elemen-elemen grafis kemasan menurut positioning produk yang diterapkan pada kemasannya. Sehingga dapat disimpulkan bahwa berkaitan dengan warna kemasan produk, produk yang ditujukan untuk kelas atas, produk elegan dan produk bermutu tinggi membutuhkan kemasan yang cenderung berwarna pekat dengan dominasi warna biru, merah dan hitam. Produk yang aman membutuhkan kemasan yang berwarna hangat dan cenderung gelap. Produk untuk kelas menengah membutuhkan kemasan yang berwarna sejuk dan oranye yang cenderung terang. Produk lokal dan produk dengan harga ekonomis membutuhkan kemasan dengan warna putih, kuning, hijau dan cenderung berwarna pudar.

Berkaitan dengan tipografi kemasan produk, untuk produk kelas atas, kemasan yang dibutuhkan adalah kemasan yang berhuruf besar, bold, berkarakter renggang dengan ukuran huruf yang besar. Untuk produk lokal dan produk yang aman, dibutuhkan kemasan dengan huruf sans serif dan dicetak tegak lurus. Kemasan untuk produk elegan, produk bermutu tinggi dan produk untuk kelas menengah menggunakan huruf script yang dicetak miring. Sedangkan produk yang memiliki harga ekonomis menggunakan jenis huruf kecil dengan tipe huruf serif, light, berkarakter sempit dan memiliki ukuran huruf yang kecil.

Berkaitan dengan bentuk grafis kemasan produk, untuk produk yang ditujukan bagi kelas atas dan produk aman adalah kemasan yang menggunakan garis vertikal, lingkaran dengan komposisi elemen yang simetris. Produk bermutu tinggi menggunakan garis lengkung, kotak dengan outline gelombang dan terdiri dari beberapa elemen. Kemasan untuk produk kelas menengah dan produk elegan adalah kemasan yang menggunakan bentuk grafis berupa garis garis zigzag dengan arah miring. Kemudian untuk produk lokal dan produk dengan harga ekonomis, kemasan menggunakan bentuk grafis berupa garis lurus yang arahnya horizontal, terdiri dari satu elemen dan menggunakan outline lurus

Berkaitan dengan gambar kemasan produk, untuk produk kelas atas dan produk yang bermutu tinggi, kemasan yang sesuai adalah kemasan yang menampilkan gambar produk. Untuk kemasan produk yang elegan menampilkan gambar berupa ilustrasi. Produk dengan harga ekonomis, produk yang ditujukan untuk kelas menengah dan produk lokal menggunakan kemasan yang menampilkan gambar berupa konsumen target yang merupakan segmen pasar produk. Kemudian untuk produk yang aman membutuhkan kemasan yang menggunakan gambar yang menunjukkan kealamian berupa fotografi. 


\section{Implikasi Manajerial}

Dari hasil analisis data yang diperoleh dapat disimpulkan bahwa konsumen memiliki persepsi terhadap kemasan produk ditinjau dari eleman grafis kemasan yaitu warna, tipografi, bentuk grafis dan gambar. Oleh karena itu disarankan bahwa dalam mendesain kemasan, perusahaan kemasan tidak boleh mengabaikan elemen grafis karena kombinasi yang tepat antara eleman grafis kemasan dapat sangat membantu perusahaan untuk mampu menciptakan kemasan yang tidak hanya menarik namun juga dapat berkomunikasi secara visual dengan baik sehingga dapat menyampaikan pesan yang ingin disampaikan kepada konsumen melalui tampilan visualnya. Sehingga hasil penelitian diharapkan dapat menjadi acuan bagi perusahaan kemasan dalam mendesain kemasan terutama dilihat dari segi grafisnya sesuai dengan positioning produk.

Namun ada beberapa keterbatasan dalam penelitian ini. Keterbatasan pertama, penelitian tidak menyertakan analisis mengenai bagaimana persepsi konsumen terhadap kemasan di masa datang. Kedua, penelitian hanya mengambil setting di kota Yogyakarta. Sehingga hasil penelitian tidak mencerminkan persepsi konsumen secara keseluruhan. Ketiga, saat responden diminta untuk mengisi kuesioner, responden hanya dihadapkan pada contoh gambar yang mewakili jenis-jenis warna, tipografi, bentuk grafis dan gambar tanpa melihat bentuk asli kemasan sehingga berpotensi menghasilkan bias karena ada kemungkinan bahwa terjadi perbedaan persepsi jika responden hanya melihat contoh kemasan dalam bentuk gambar dibandingkan dengan melihat kemasan secara langsung. Keempat, dalam penelitian ini tidak diketahui dengan pasti apakah terdapat responden yang buta warna atau tidak. Jika ternyata di dalam penelitian ada responden yang buta warna maka berpotensi menghasilkan bias pada penelitian.

Maka saran untuk penelitian selanjutnya adalah lingkup penelitian sebaiknya dilakukan dengan setting budaya yang berbeda untuk mengetahui apakah ada perbedaan persepsi konsumen terhadap warna, tipografi, bentuk grafis dan gambar dilihat dari perbedaan nilainilai budaya. Kedua, perlu dilakukan perbaikan pada teknik pengumpulan data. Sebaiknya saat responden diminta untuk mengisi kuesioner, responden benar-benar dihadapkan pada bentuk asli kemasan. Sehingga responden dapat lebih mudah untuk menilai warna, tipografi, bentuk grafis dan gambar yang sesuai untuk masing-masing produk dan stimulus yang diterima responden jika melihat kemasan produk secara nyata lebih kuat jika dibandingkan hanya melihat contoh kemasan dalam bentuk gambar. Ketiga, responden untuk penelitian sebaiknya benar-benar dipastikan tidak ada yang buta warna. Misalnya dengan melakukan tes buta warna sebelum melakukan penelitian lebih lanjut agar responden benar-benar dapat mengenali dan membedakan warna dengan tepat. Sehingga tidak terjadi bias pada penelitian.

\section{DAFTAR REFERENSI}

Ampuero, Olga dan Natalia Vila. 2006. "Consumer Perceptions Of Product Packaging". Journal Of Consumer Marketing. Vol. 23 No.2.

Klimchuk, Marienne Rosner dan Sandra A. Krasovec. 2007. Desain Kemasan Perencanaan Merek Produk yang Berhasil Mulai dari Konsep Sampai Penjualan. Jakarta : Erlangga.

Kuncoro, Mudrajad. 2003. Metode Riset Untuk Bisnis Ekonomi . Jakarta : Erlangga.

Kusrianto, Andi. 2007. Pengantar Desain Komunikasi Visual. Yogyakarta : ANDI.

Schiffman, Leon dan Leslie Lazar Kanuk. (2007). Perilaku Konsumen. Jakarta : PT Indeks.

Shimp, A. Terence. 2003. Periklanan Promosi Aspek Tambahan Komunikasi Pemasaran Terpadu. Edisi Kelima. Jakarta : Erlangga.

Sihombing, Danton. 2001. Tipografi Dalam Desain Grafis. Jakarta: Gramedia Pustaka Utama. Simamora, Bilson. 2005. Analisis Multivariat Pemasaran. Jakarta : Gramedia Pustaka Utama. Singarimbun, Masri dan Sofian Effendi. 1987. Metode Penelitian Survei. Yogyakarta : BPFE. Suliyanto. 2006. Metode Riset Bisnis. Yogyakarta : ANDI. 
Ariesta Sekarlaranti

Shellyana Junaedi

Tjiptono, Fandy. 1997. Strategi Pemasaran. Edisi II. Yogyakarta : ANDI.

http://brandexcentric.blogspot.com/2006/08/packaging-industry-review.html (23 Februari 2008)

http://elmu.umm.ac.id/statistik/statmet/Analisis/Analisis\%20Korespondensi.htm(23 Februari 2008)

http://faculty.petra.ac.id (23 Februari 2008)

http://www.marketing.co.id/Common/File.ashx?ld=4621 (23 Februari 2008)

www.worqx.com/color (4 Juni 2008) 